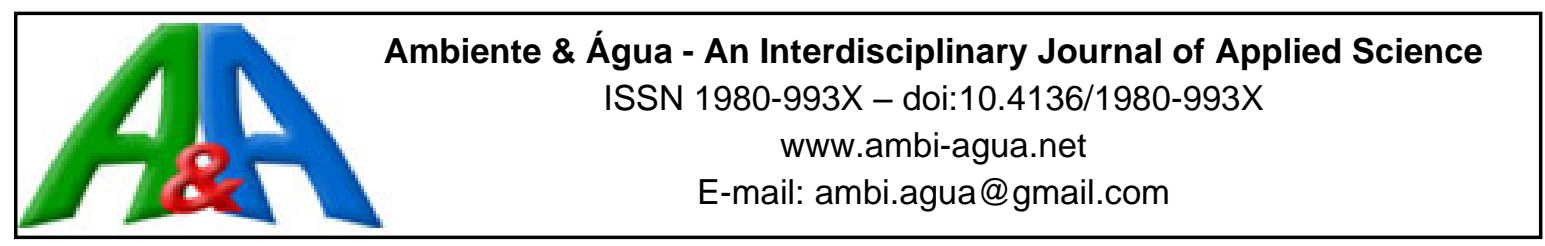

\title{
The effect of SDS surfactant on surface reaeration coefficient: a laboratory scale approach
}

\author{
ARTICLES doi:10.4136/ambi-agua.2536
}

Received: 03 Mar. 2020; Accepted: 22 Jun. 2020

\section{Murilo de Souza Ferreira ${ }^{1}$; Thiago Vinicius Ribeiro Soeira ${ }^{2}$; Deusmaque Carneiro Ferreira ${ }^{2}$; Mário Sergio da Luz $^{2}{ }^{(D}$; Cristiano Poleto ${ }^{3}$; Julio Cesar de Souza Inácio Gonçalves ${ }^{2 *}$ (D)}

\footnotetext{
${ }^{1}$ Departamento de Hidráulica e Saneamento. Laboratório de Biotoxicologia de Águas Continentais e Efluentes. Escola de Engenharia de São Carlos da Universidade de São Paulo (EESC-USP), Avenida Trabalhador SãoCarlense, $n^{\circ}$ 400, CEP: 13566-590, São Carlos, SP, Brazil. E-mail: sfmurilo1@gmail.com ${ }^{2}$ Programa de Pós-Graduação em Ciência e Tecnologia Ambiental. Instituto de Ciências Exatas e Tecnológicas. Universidade Federal do Triângulo Mineiro (UFTM), Avenida. Dr. Randolfo Borges Júnior, $n^{\circ}$ 1400, CEP: 38064-200, Uberaba, MG, Brazil. E-mail: tvribeiro88@hotmail.com, deusmaque@hotmail.com, mariosergiodaluz2013@gmail.com

${ }^{3}$ Departamento de Hidromecânica e Hidrologia. Instituto de Pesquisas Hidráulicas. Universidade Federal do Rio Grande do Sul (UFRGS), Avenida Bento Gonçalves, n 9500, CEP: 91501-970, Porto Alegre, RS, Brazil. E-mail: cristiano.poleto@ufrgs.br *Corresponding author. E-mail: sigjulio@gmail.com
}

\begin{abstract}
Surface reaeration coefficient $\left(\mathrm{K}_{2}\right)$, which represents the transfer of oxygen at the air-water interface, is an important variable in aquatic ecosystems. $K_{2}$ is influenced by several factors, including surfactants; furthermore, this coefficient is used in water-quality models, which requires its correct estimation. This study evaluated the effects of the surfactant Sodium Dodecyl Sulfate (SDS) on $\mathrm{K}_{2}$ in two different experimental systems. In a cylindrical reactor with a turbine-type mechanical stirrer, 15 reaeration experiments were carried out with SDS concentrations of $0.0 ; 0.25 ; 0.5 ; 1.0$ and $1.5 \mathrm{mMol} \mathrm{L}^{-1}$ and stirrer rotation velocities of 25,50 and $100 \mathrm{rpm}$. In a circular hydraulic channel, 8 reaeration experiments were carried out, in triplicate, with SDS concentrations of 0 and $1.5 \mathrm{mMol} \mathrm{L}^{-1}$ and agitation levels of Reynolds $4,500,37,500 ; 49,200$ and 54,000. In the reactor, regardless of the rotation velocity, the surfactant reduced $\mathrm{K}_{2}$ by $20 \%$, due to a superficial film formation at the interface that made oxygen transfer difficult, due to a phenomenon known as "barrier effect". In the channel, an approximate $\mathrm{K}_{2}$ reduction of $15 \%$ occurred at higher levels of water agitation. In the presence of surfactants, and at low levels of agitation, phenomena that increase $\mathrm{K}_{2}$ (i.e., Marangoni effect) may coexist with those that reduce $K_{2}$ (i.e., barrier effect). We concluded that the presence of SDS in aquatic environments should be considered when estimating the surface reaeration coefficient, because this surfactant can contribute to uncertain $\mathrm{K}_{2}$ estimation.
\end{abstract}

Keywords: surface reaeration, surfactants, water quality modeling.

\section{O efeito do surfactante SDS sobre o coeficiente de reaeração superficial: uma abordagem em escala laboratorial}

\section{RESUMO}

O coeficiente de reaeração superficial $\left(\mathrm{K}_{2}\right)$, que representa a transferência de oxigênio na 
interface ar-água, é uma importante variável dos ecossistemas aquáticos. O $\mathrm{K}_{2}$ é influenciado por diversos fatores, entre eles as substâncias surfactantes, além disso, tal coeficiente é utilizado em modelos de qualidade da água, o que demanda a sua correta estimativa. O objetivo deste trabalho foi avaliar o efeito do surfactante Dodecil Sulfato de Sódio (SDS) sobre o $\mathrm{K}_{2}$. Em um reator cilíndrico com agitador mecânico tipo turbina, 15 experimentos de reaeração foram realizados com concentrações de $\operatorname{SDS}\left(0,0 ; 0,25 ; 0,5 ; 1,0\right.$ e $\left.1,5 \mathrm{mMol} \mathrm{L}^{-1}\right)$ e velocidades de rotação do agitador $(25,50$ e $100 \mathrm{rpm})$. Em um canal hidráulico circular, 8 experimentos de reaeração foram realizados, em triplicata, com concentrações de SDS $\left(0\right.$ e $\left.1.5 \mathrm{mMol} \mathrm{L}^{-1}\right)$ e níveis de agitação (Reynolds 4.500, 37.500, 49.200 e 54.000). No reator, independentemente da velocidade de rotação, o surfactante reduziu o $\mathrm{K}_{2}$ em $20 \%$, devido à formação de um filme superficial na interface que dificultou a transferência do oxigênio, fenômeno conhecido como efeito barreira. No canal, a redução de $\mathrm{K}_{2}$ (aproximadamente $15 \%$ ) ocorreu em maiores níveis de agitação da água. Na presença de surfactantes, e em baixos níveis de agitação, fenômenos que aumentam o $\mathrm{K}_{2}$ (i.e., efeito de Marangoni) coexistem com os que reduzem $\mathrm{K}_{2}$ (i.e., efeito barreira). Conclui-se que a presença de SDS em ambientes aquáticos deve ser considerada na estimativa do coeficiente de reaeração superficial, pois este surfactante pode contribuir para estimativas incertas do $\mathrm{K}_{2}$.

Palavras-chave: modelagem da qualidade da água, reaeração superficial, surfactantes.

\section{INTRODUCTION}

The transfer of gases through the air-water interface is an important step in the biogeochemical cycles of numerous substances (helium, nitrogen, carbon and oxygen), and for that reason is often required in many fields of science and engineering (Janzen et al., 2008). Recently, due to increasing concern about global warming, there is an intense interest in studying the transfer of carbon dioxide $\left(\mathrm{CO}_{2}\right)$ and other greenhouse gases between the atmosphere and water. It was estimated that 30 to $40 \%$ of $\mathrm{CO}_{2}$ emitted by human activities is absorbed by the ocean; however, this estimate is significantly affected by the uncertainty in predicting gas transfer rate at the air-water interface (Banerjee, 2007).

Even in the current context, which imposes the study of gases linked to the effects of atmospheric warming, special attention should still be maintained for oxygen transfer (Janzen et al., 2008; Gonçalves et al., 2013; Menezes et al., 2015; Costa et al., 2015; Harano et al., 2018). In practice, the interest in this subject relates to the modeling of dissolved oxygen (DO) dynamics downstream from organic sources of pollution; since the biodegradation process of organic waste causes the decay of DO concentration (Costa and Texeira, 2011; Gonçalves et al., 2012; Gonçalves and Giorgetti, 2013; Mateus et al., 2015; Gonçalves and Esposto, 2019). In rivers, the main source of DO recovery is oxygen transfer at the air-water interface. This phenomenon is also known as "surface reaeration". Advances in knowledge about oxygen absorption by water bodies results in improved quantification of reaeration rate, which is an essential parameter of water quality models and which the environmental and water body recovery analyses are based (Gonçalves et al., 2017; 2018; Ferreira et al., 2019; 2020).

Gas transfer is controlled by a complex interaction between molecular diffusion and turbulent phenomena near the interface. Assuming that the transfer process is horizontally homogeneous, the oxygen mass rate through the air-water interface is usually expressed by Equation 1:

$$
\frac{d C}{d t}=\frac{K_{L} A}{V}\left(C_{s}-C\right)
$$

Where $\mathrm{V}$ is the water body volume, $\mathrm{A}$ is the air-water interface area, $\mathrm{C}$ is the DO

Rev. Ambient. Água vol. 15 n. 4, e2536 - Taubaté 2020 
concentration, $\mathrm{C}_{\mathrm{s}}$ is the DO saturation concentration, $\mathrm{K}_{\mathrm{L}}$ is the DO mass transfer coefficient, and $t$ is the time. The $\mathrm{K}_{\mathrm{L}} \mathrm{A} / \mathrm{V}$ ratio is known as the "surface reaeration coefficient", which is represented by the parameter $\mathrm{K}_{2}$.

Since the early twentieth century, several researchers have tried to understand the phenomenon of oxygen mass transfer and to develop conceptual and empirical models capable of relating the $\mathrm{K}_{2}$ coefficient to physical flow parameters (Lewis and Whitman, 1924; Moog and Jirka, 1999; Gualtieri et al., 2002; Herlina, 2005). Despite advances in understanding how free-surface hydrodynamics influences the interfacial heat and mass transfer (as presented by Menni and Azzi, 2018), a few studies have investigated the effect of surface films on $\mathrm{K}_{2}$ such as surfactant compounds. Most studies point out that the presence of surfactants may reduce the $\mathrm{K}_{2}$ coefficient due to a film formation in the free surface that its makes difficult to transfer atmospheric oxygen to the liquid volume (Rosso et al., 2006; Jamnongwong et al., 2010; Silva et al., 2020). Contrary to this, other studies have reported that the presence of surfactants increases $\mathrm{K}_{2}$ variability at different turbulence levels (Mackenna and Mcgillis, 2004). Silva et al. (2020) used an oscillating grid tank to investigate the effect of humic substances, a surfactant compound, on $\mathrm{K}_{2}$ at different turbulence levels. They concluded that a relationship between $\mathrm{K}_{2}$ and turbulence showed that in the presence of humic substances, the air-water interface behaves like an immobile surface, reducing the oxygen diffusion and surface renewal.

Surfactant compounds are often employed in the manufacture of pharmaceuticals, cosmetics and detergents (Moraveji et al., 2011). They reach water bodies due to the release of wastewater (with or without treatment). In water bodies, surfactants can be found in two forms: monomers and micelles. Monomers are free molecules, which have hydrophilic and hydrophobic regions. Micelles are large aggregates of surfactant molecules dispersed in a liquid colloid. The concentration of surfactants in which micelles are formed is called "critical micellar concentration" (CMC). Above CMC, the surface film becomes practically homogeneous and the cohesive force of surfactant molecules near the surface becomes unlikely to change (Behring et al., 2004).

The effect of surfactants on $\mathrm{K}_{2}$, in a first approach, should be studied in laboratory scale, where it is possible to isolate the influence of other factors on the transfer phenomenon (e.g., temperature, water salinity, $\mathrm{pH}$, and so on). Additionally, in laboratory scale it is possible to perform a more systematic study varying the surfactant amount and also the hydrodynamic turbulence level. In fact, in laboratory scale, many water-stirring systems have been used to generate different turbulence levels, such as oscillating grid tanks, turbine-type mechanical agitator tanks, recirculating hydraulic channels, and jet-agitated tanks. Such equipment can generate turbulence in a controlled manner, simulating natural environments such as rivers and lakes (Janzen et al., 2009).

In estimating this coefficient, most studies related to oxygen transfer at the air-water interface do not consider the effect of surfactant compounds; therefore, the importance of this study stands out. If $\mathrm{K}_{2}$ is incorrectly measured, and so underestimated, cost will be incurred as a result to improve wastewater treatment plants to achieve the water quality satisfactory levels in water bodies that are wastewater receivers. On the other hand, if $K_{2}$ is overestimated, serious damage may be caused to these water bodies which have low self-depuration.

This paper studied the effects of surfactant compounds on $\mathrm{K}_{2}$. The compound with surfactant characteristics analyzed was Sodium Dodecyl Sulphate (SDS,) which is an anionic surfactant present in most commercial detergents and, consequently, is commonly found in aquatic environments. For this purpose, reaeration experiments were conducted at a laboratory scale, performed in a turbine-type mechanical stirrer reactor and in a circular hydraulic channel, with surfactant concentrations ranging from zero to CMC. 


\section{MATERIALS AND METHODS}

\subsection{Apparatus and reagents}

The reaeration experiments were conducted in a turbine-type mechanical stirrer reactor (Figure 1a and 1b) and in a circular hydraulic channel (Figure 1c and 1d).

The reactor used in the present study had a diameter of $0.135 \mathrm{~m}$ with a volume of $2 \mathrm{~L}$. A two-blade turbine agitator was used to control interfacial turbulence, adjusting the rotation velocity (RS). The RS, which ranged from $25 \mathrm{rpm}$ to $100 \mathrm{rpm}$, was adopted in our experiments as water turbulence levels.

(a)

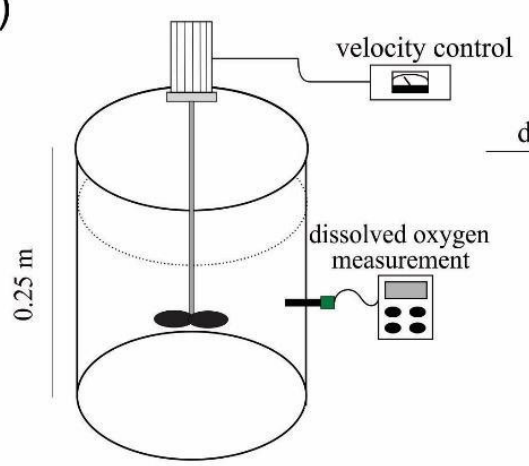

(c)

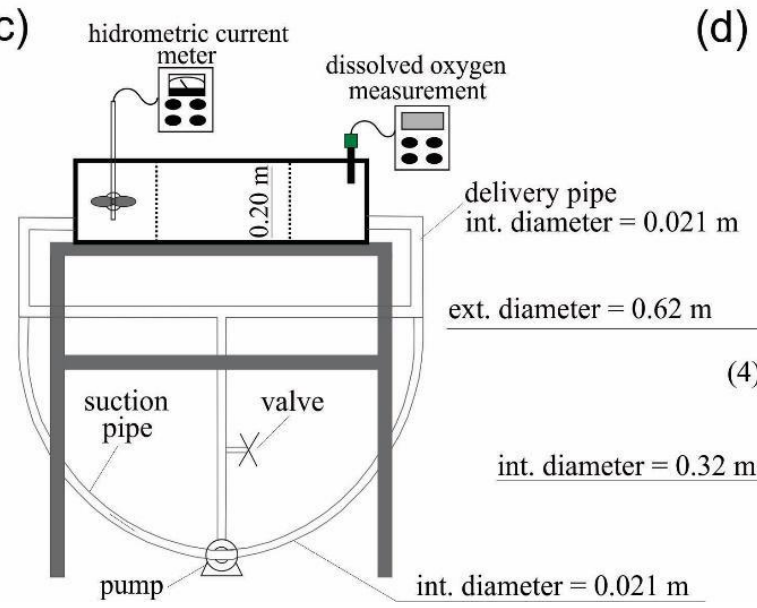

(b)

diameter $=0.135 \mathrm{~m}$

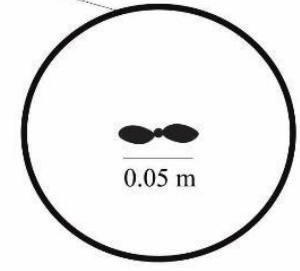

(d)

velocity measurements

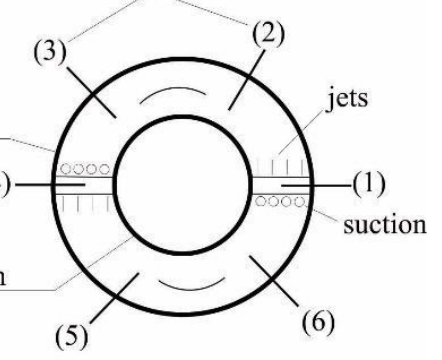

(5)

(6)

Figure 1. Experimental Apparatus: (a) longitudinal section of cylindrical reactor with mechanical stirrer, (b) top view of cylindrical reactor, (c) longitudinal section of circular hydraulic channel, (d) top view of circular hydraulic channel.

The circular hydraulic channel was constructed with fiberglass reinforced polymer. Jets resulting from the recirculation of water in the channel generate the water turbulence in this system. A $0.25 \mathrm{hp}$ motor-pump system was connected to two suction and delivery points distributed along the channel in a closed circuit. The experiments were performed for 1.5 to 8 hours. During all experiments, the channel and all measurement setups were kept at a controlled room temperature. Water temperature, during the experiments, was controlled and stabilized by a serpentine heat exchanger, fixed between the channel and the pump. In order to obtain different water velocities (U) and turbulence levels, a register was installed in the delivery pipe. $\mathrm{U}$ was measured using hydrometric current meter (1\% accuracy) located at six different points along the channel, and at a depth equivalent to $50 \%$ of the water column. The description of the hydraulic conditions in the channel is shown in Table 1. The different agitation levels were characterized according to the Reynolds number, which is given by Equation 2. 
Table 1. Hydraulic conditions established in the circular hydraulic channel.

\begin{tabular}{ccccc}
\hline Experiments & $\mathbf{U}\left(\mathbf{m ~ s}^{-1}\right)$ & Rey (-) & H (m) & Volume $(\mathbf{L})$ \\
\hline 1 & 0.03 & 4,500 & 0.15 & 32.6 \\
2 & 0.25 & 37,500 & 0.15 & 32.6 \\
3 & 0.41 & 49,200 & 0.12 & 26.4 \\
4 & 0.60 & 54,000 & 0.09 & 20.2 \\
\hline
\end{tabular}

$\operatorname{Rey}=\frac{U H}{v}$

Where $\mathrm{U}$ is the water flow velocity $\left(\mathrm{m} \mathrm{s}^{-1}\right), \mathrm{H}$ is the depth $(\mathrm{m})$ and $v$ is the water kinematic viscosity $\left(110^{6} \mathrm{~m}^{2} \mathrm{~s}^{-1}\right)$.

Dissolved oxygen and water temperature were measured using a multiparameter probe (Hach model HQ40D) with an attached LDO 101 sensor (accuracy $0.1 \mathrm{mg} \mathrm{L}^{-1}$ ).

The anionic surfactant used was the ultrapure Sodium Dodecyl Sulfate (SDS) (Sigma Aldrich, 99\%). Surfactant CMC was determined by Mateus et al. (2019), using an electrical conductivity method, they showed that for the water used in this study (i.e., tap water with 80 $\mathrm{mg} \mathrm{L}^{-1}$ salinity) CMC ranged from 1.5 to $1.6 \mathrm{mMol} \mathrm{L}^{-1}$.

\subsection{Surface reaeration experiments}

The surfactant solutions were prepared on the apparatus by mixing the SDS salt in the base fluid (tap water with $80 \mathrm{mg} \mathrm{L}^{-1}$ salinity). Under atmospheric pressure $(938.2 \mathrm{hPa})$, reaeration experiments were performed using the balance disturbance technique. Initially, dissolved oxygen was removed from the solution using nitrogen gas (Stripping method). When the oxygen concentration reached values close to $2 \mathrm{mg} \mathrm{L}^{-1}$, the nitrogen hose was removed from the apparatus and the reaeration process began. The experiment ended when the DO concentration approached its saturation concentration close to $8.0 \mathrm{mg} \mathrm{L}^{-1}$.

The fit of the analytical solution of Equation 1 to the observed data and, consequently, the estimation of $\mathrm{K}_{2}$ was performed using the nonlinear regression analysis technique. The analytical solution of Equation 3 is:

$$
C(t)=C_{s}-\left(C_{s}-C_{0}\right) \exp \left(-K_{2} t\right)
$$

Where $\mathrm{C}$ is the DO concentration $\left(\mathrm{mg} \mathrm{L}^{-1}\right), \mathrm{C}_{0}$ is the initial DO concentration $\left(\mathrm{mg} \mathrm{L}^{-1}\right), \mathrm{C}_{\mathrm{s}}$ is the DO saturation concentration $\left(\mathrm{mg} \mathrm{L}^{-1}\right)$.

The water temperature, during the experiments, ranged approximately $\pm 3^{\circ} \mathrm{C}$ and all $\mathrm{K}_{2}$ values were corrected to $20^{\circ} \mathrm{C}$ using the simplified Arrhenius Equation 4:

$$
K_{2}(20)=\frac{K_{2}(T)}{\theta^{(T-20)}}
$$

Where $\mathrm{T}$ is the mean water temperature in the reaeration experiments $\left({ }^{\circ} \mathrm{C}\right)$ and $\theta$ is the temperature correction coefficient, whose value was 1.0241, as recommended by Elmore and West (1961).

In total, 15 reaeration experiments were performed in the cylindrical reactor. Each experiment was characterized by the pair: SDS concentration $(0.0,0.25,0.50,1.0$, $\left.1.5 \mathrm{mMol} \mathrm{L}^{-1}\right)$ and rotation velocity $(25,50$ and $100 \mathrm{rpm})$. In the circular hydraulic channel, experiments were performed in triplicate for each Reynolds number. However, only two concentrations of SDS were tested: zero concentration and the concentration that had the greatest effect on $\mathrm{K}_{2}$ in the cylindrical reactor tests. In total, 24 experiments were conducted in the channel. 
The SDS effect on $\mathrm{K}_{2}$ was evaluated by factor $\alpha$ (Equation 5).

$\alpha=\frac{K_{2} \text { with } S D S}{K_{2} \text { without } S D S}$

Where $\alpha$ is the ratio factor between water $\mathrm{K}_{2}$ with and without SDS (dimensionless).

This evaluation methodology was developed by Gillot et al. (2000) and Jamnongwong et al. (2010), where for $\alpha$ equals to 1 , the surfactant does not influence the reaeration phenomenon. When $\alpha$ is greater than 1 , the surfactant accelerates the oxygen mass transfer to water, and when $\alpha$ is less than 1, it means that the surfactant represents a resistance to the oxygen transfer.

\section{RESULTS AND DISCUSSION}

\subsection{Surface reaeration}

Figure 2a shows the surface reaeration curves without SDS generated by different rotational velocities of the mechanical stirrer in the cylindrical reactor, and for different Reynolds numbers in the circular hydraulic channel (Figure 2b). The excellent fit between Equation 3 and the experimental data is observed. The adjustment presented $\mathrm{R}^{2}>0.96$ for all experiments. Based on this result, Equation 3 can be used to model the surface reaeration phenomenon in the apparatus used in this study. It is also noted that the reaeration curves reach the DO saturation concentration faster as the agitation level rises in the cylindrical reactor (i.e., increased turbine rotation velocity) and in the circular hydraulic channel (i.e., increased Reynolds number). The higher agitation caused greater interfacial turbulence. This turbulence plays a key role in the exchange of oxygen at the interface, as it reduces the thickness of the boundary layer, increasing the concentration gradient and, consequently, the diffusion of oxygen in water (Herlina and Jirka, 2008; Zhang et al., 2013).

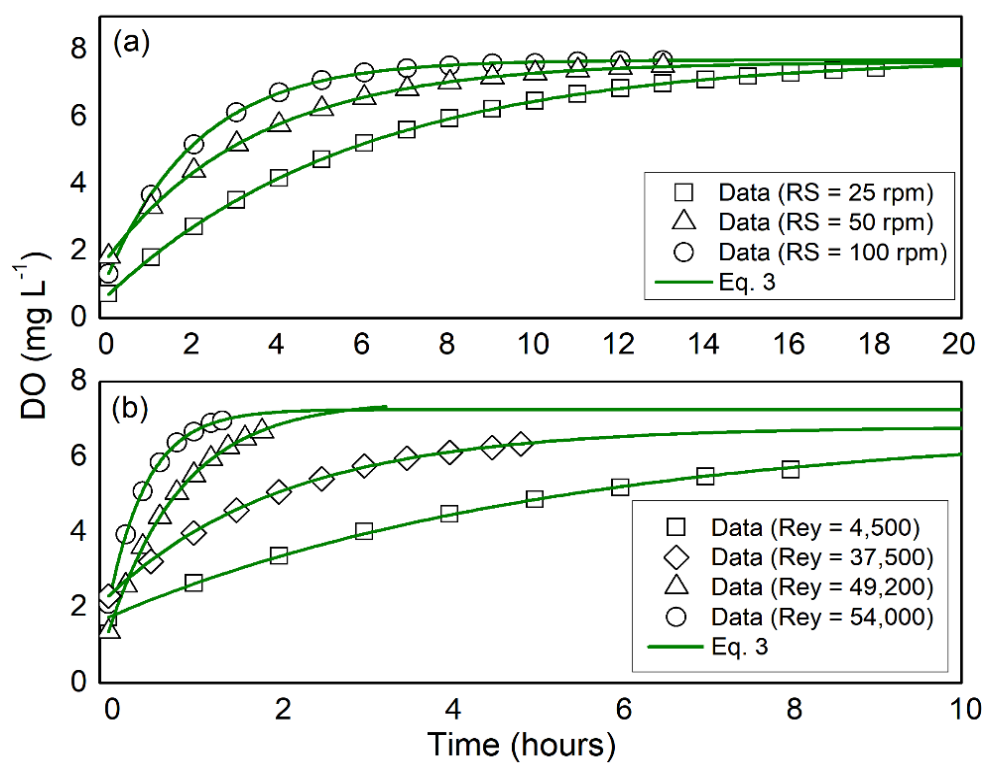

Figure 2. Surface reaeration curves obtained in the (a) cylindrical reactor with mechanical stirrer and (b) circular hydraulic channel.

\subsection{Effect of SDS surfactant on surface reaeration coefficient}

Figure 3 presents the values of reaeration coefficient for the cylindrical reactor, considering the three turbulence levels and for five different SDS concentrations. Additionally, the ratio factor $\alpha$ is also shown. 

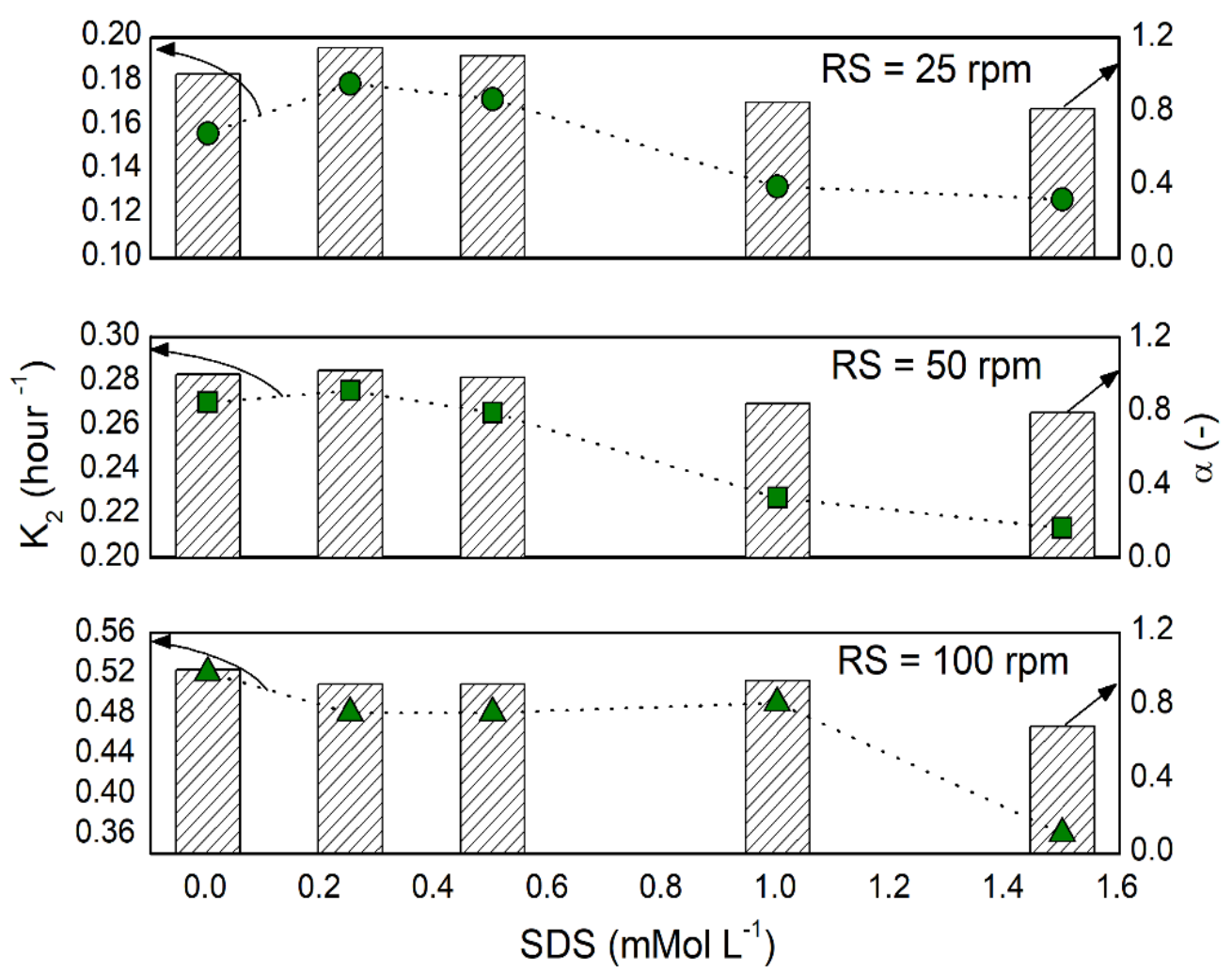

Figure 3. Effect of SDS on reaeration coefficient in the cylindrical reactor.

SDS concentrations up to $0.5 \mathrm{mMol} \mathrm{L}^{-1}$ has little effect on $\mathrm{K}_{2}$. However, at all agitation levels, the $\mathrm{K}_{2}$ value decreased by about $20 \%(\alpha=0.8)$ when the SDS concentration reached the critical micellar concentration (SDS $=1.5 \mathrm{mMol} \mathrm{L}^{-1}$ ). Similar results to this $\mathrm{K}_{2}$ reduction in the CMC zone were obtained by Rosso et al. (2006), who performed diffuse air reaeration experiments, and obtained a $\mathrm{K}_{2}$ reduction of approximately 30 to $70 \%$ for pure water. The greatest reduction in this concentration range can be explained due to the surface film responsible for the resistance to oxygen mass transfer, which is completely formed when the surfactant concentration reaches the CMC (as presented by Santos et al., 2007).

A scheme to show surface occupancy by surfactant molecules is shown in Figure 4. For concentrations below the $\mathrm{CMC}$, the surface film is not completely formed. On the other hand, close to CMC the entire free surface is occupied by the surfactant molecules. This condition reduces the oxygen diffusion coefficient, as shown by Jamnongwong et al. (2010) and Jimenez et al. (2014). Additionally, the surface film can reduce the number of surface breaking motions, which are the result of eddy's that reach the surface randomly (Mckenna and Mcgillis, 2004). These movements are essential for surface renewal and interface oxygen transfer. The difficulty in oxygen transfer caused by surface film resistance is known as a "barrier effect" (Mateus et al., 2019).

Figure 5 shows $\alpha$ values for circular hydraulic channel when SDS concentration reaches CMC (1.5 mMol L-1). The smallest $\alpha$ values (approximately 0.85 ) were obtained when the flow in the channel was more turbulent (Reynolds 49,200 and 54,000). For the lowest Reynolds values, SDS had no effect on $\mathrm{K}_{2}(\alpha=1)$. This can be explained by the existence of another phenomenon on oxygen transfer, besides the barrier effect produced by the surface film. This phenomenon is known as the "Marangoni effect". It occurs at low Reynolds numbers and acts to accelerate oxygen transfer, contrary to the effect produced by the surface film. Zhang et al. (2013) showed that the Marangoni effect is only significant at low water agitation levels and occurs due to the formation of a surface tension gradient near the surface. At high turbulence levels, the Marangoni effect becomes negligible. 


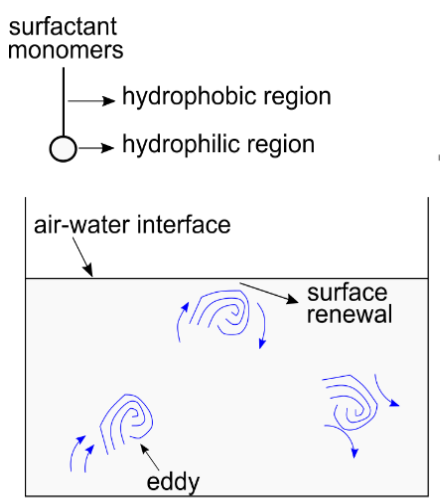

clean water

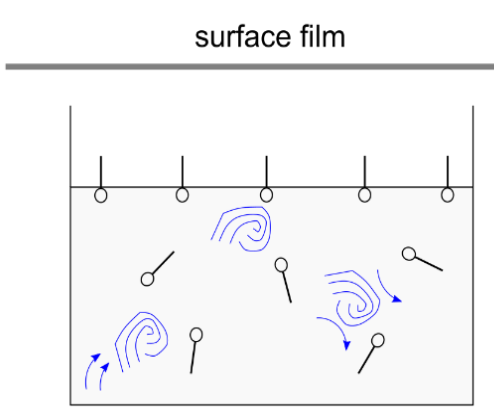

water containing surfactant below $\mathrm{CMC}$

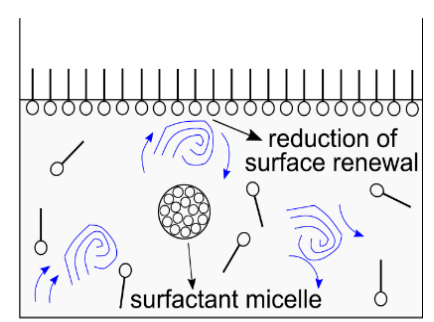

water containing surfactant at $\mathrm{CMC}$

Figure 4. Representative scheme of the behavior of SDS molecules at the air-water interface.

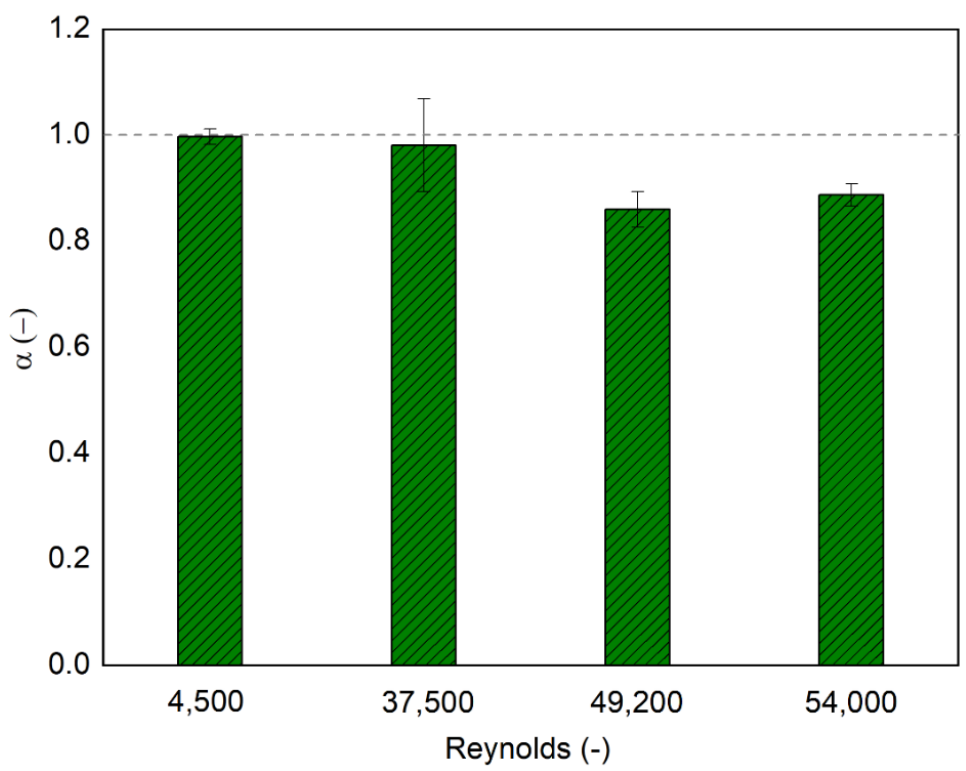

Figure 5. Effect of SDS on $\alpha$ in circular hydraulic channel.

The surface tension gradient, formed by the existence of an SDS concentration gradient, produces convective movements in the boundary layer of the air-water interface, which in turn renews the surface by increasing oxygen transfer (Zhang et al., 2013). A schematic diagram of the convective currents formed by the Marangoni effect at the interface is shown in Figure 6.

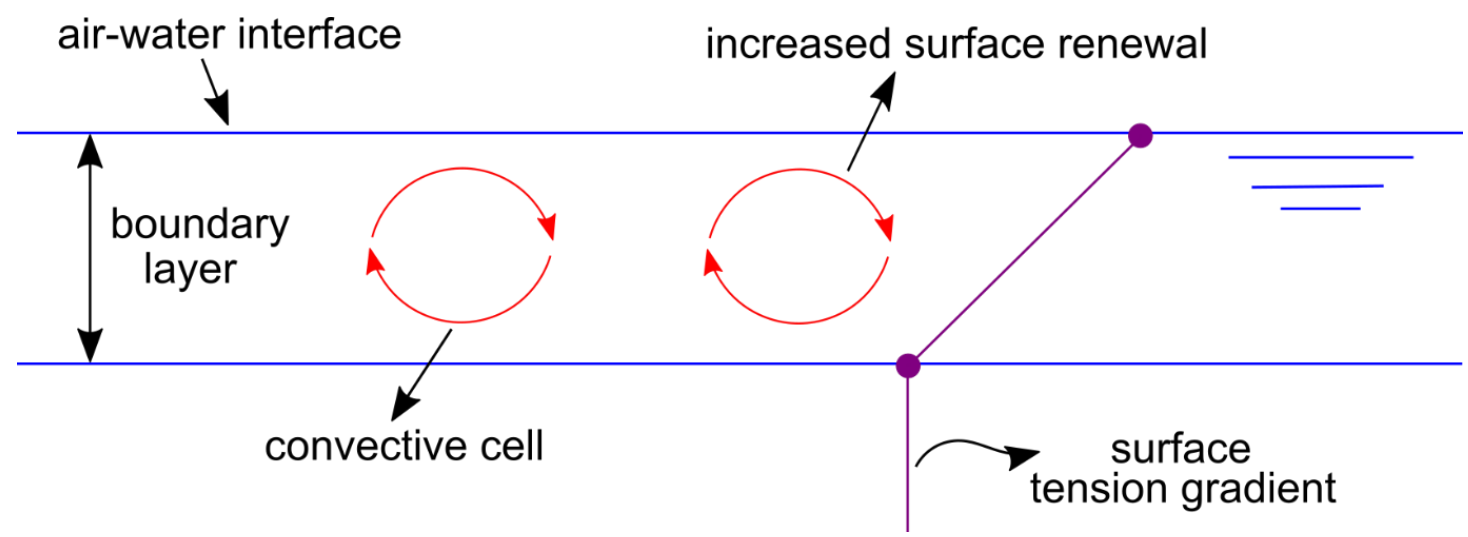

Figure 6. Representative scheme of Marangoni effect on air-water interface in the presence of surfactant. 


\section{CONCLUSIONS}

This work evaluated the effect of SDS surfactant on the surface reaeration phenomenon. For this purpose, a turbine-type mechanical stirrer reactor and a circular hydraulic channel were used. The main conclusions are:

- The SDS reduces the surface reaeration coefficient by around $20 \%$ in the reactor and $15 \%$ in the circular hydraulic channel.

- The greatest reduction occurs when SDS concentration reaches CMC. In this condition, the air-water interface is entirely occupied by SDS molecules and therefore the barrier effect is maximized.

- At low turbulence, the effect of SDS on the reaeration coefficient is nonexistent, since for this condition there are two phenomena combined, one that reduces the reaeration coefficient (barrier effect) and another that increases the reaeration coefficient (Marangoni effect).

We recognize that the contributions of this study were samples and limited, and the results are restricted to the conditions under which the experiments were carried out. However, the SDS is a surfactant present in many commercial detergents and is commercialized worldwide; consequently, such surfactant reaches natural water bodies mainly through wastewater. This study therefore showed that the presence of this compound should be considered in the estimation of the $\mathrm{K}_{2}$, as it is an important parameter of water quality models which are used to estimate the self-depuration capacity of natural flows. We recommend that future studies of reaeration be carried out in real environments, natural water bodies, especially those that are wastewater receivers.

\section{ACKNOWLEDGEMENTS}

The authors are grateful to Conselho Nacional de Desenvolvimento Científico e Tecnológico (CNPq: 444644/2014-8), for its support. Anonymous reviewers provided quite valuable comments for improving this manuscript.

\section{REFERENCES}

BANERJEE, S. The air water interface: turbulence and scalar exchange. In: GARBE, C. S.; HANDLER, R. A.; JÄHNE, B. (Eds.) Transport at the air-sea interface. Berlin: Springer, 2007. p. 87-101.

BEHRING, J. L.; LUCAS, M.; MACHADO, C.; BARCELLOS, I. O. Adaptação no método do peso da gota para determinação da tensão superficial: um método simplificado para a quantificação da cmc de surfactantes no ensino da química. Química Nova, v. 27, n. 3, p. 492 -495, 2004. https://doi.org/10.1590/S0100-40422004000300021

COSTA, D. J. L.; TEIXEIRA, D. Análise de incerteza em um modelo matemático de qualidade da água aplicado ao Ribeirão do Ouro, Araraquara, SP, Brasil. Revista Ambiente \& Água, v. 6, n. 2, p. 232-245, 2011. http://dx.doi.org/10.4136/ambi-agua.196

COSTA, D. J. L.; GONÇALVES, J. C. S. I.; PORTO, R. M.; GIORGETTI, M. F. Modelo semiempírico para obtenção do coeficiente de reoxigenação superficial em canais hidráulicos. Revista Brasileira de Recursos Hídricos, v. 20, n. 1, p. 16-23, 2015. https://dx.doi.org/10.21168/rbrh.v20n1.p16-23 
ELMORE, H. L.; WEST, W. F. Effect of water temperature on stream reaeration. Journal of the Sanitary Engineering Division, v. 87, n. SA6, p. 59-71, 1961.

FERREIRA, M. S.; OLIVEIRA, R.V.; URZÊDO, L. E. S.; LOPES JÚNIOR, G. B.; GONÇALVES, J. C. S. I. Estimativa do coeficiente de transferência de massa de oxigênio com o uso da técnica das sondas solúveis flutuantes: um estudo de laboratório. Engenharia Sanitária e Ambiental, Rio de Janeiro, v. 24, n. 2, p. 1-12, 2019. https://dx.doi.org/10.1590/S1413-41522019173205

FERREIRA, M. S.; MAYNARDES, C. E. K.; JORDÃO, A. C.; GONÇALVES, J. C. S. I.; DODDS, W. K.; CUNHA, D. G. F. Surface Reaeration in Tropical Headwater Streams: the Dissolution Rate of a Soluble Floating Probe as a New Variable for Reaeration Coefficient Prediction. Water, Air, \& Soil Pollution, v. 231, p. 58, 2020. https://dx.doi.org/10.1007/s11270-019-4391-7

GILLOT, S.; CAPELA, S.; HEDUIT, A. A. Effect of horizontal flow on oxygen transfer in clean water and clean water with surfactants. Water Research, v. 34, n. 2, p. 678-683, 2000. https://doi.org/10.1016/S0043-1354(99)00167-0

GONÇALVES, J. C. de S. I.; ESPOSTO, M. S. Water quality modeling of the São Joaquim stream, Brazil. Ciência e Natura, v. 41, n. e14, p. 01-13, 2019. http://dx.doi.org/10.5902/2179460x35540

GONÇALVES J. C. S. I.; GIORGETTI, M. F. Mathematical model for the simulation of water quality in rivers using the Vensim PLE Software. Journal of Urban and Environmental $\begin{array}{lllllll}\text { Engineering, } & \text { v. } & 7, & \text { n. } & 1, & \text { p. } & 48-63,\end{array}$ https://dx.doi.org/10.4090/juee.2013.v7n1.048063

GONÇALVES, J. C. S. I.; COSTA, D. J. L.; SILVEIRA, A.; GIORGETTI, M. F. Reoxigenação superficial e sumidouro físico de oxigênio dissolvido em um tanque agitado por jatos. Revista Brasileira de Recursos Hídricos, v. 18, n. 3, 231-240, 2013.

GONÇALVES, J. C. S. I.; SARDINHA, D. S.; DE SOUZA; A. D. G.; DIBIAZI, A. L. B.; GODOY, L. H.; CONCEIÇÃO, F. T. Avaliação espaço-temporal da qualidade da água e simulação de autodepuração na bacia hidrográfica do córrego São Simão, SP. Revista Ambiente \& Água, v. 7, n. 3, p.141-154, 2012. https://dx.doi.org/10.4136/ambi-agua.894

GONÇALVES, J. C. S. I.; SILVEIRA, A.; LOPES JÚNIOR, G. B.; da LUZ, M. S.; SIMÕES, A. L. A. Reaeration coefficient estimate: new parameter for predictive equations. Water, Air, \& Soil Pollution, v. 228, n. 307, p. 1-10, 2017. https://dx.doi.org/10.1007/s11270017-3491-5

GONÇALVES, J. C. S. I.; SILVEIRA, A.; LOPES JÚNIOR, G. B.; da LUZ, M. S.; GIORGETTI, M. F. Evaluation of reaeration by convective heat transfer coefficient. Journal of Environmental Engineering, v. 144, n. $2, \quad 2018$. https://doi.org/10.1061/(ASCE)EE.1943-7870.0001308

GUALTIERI, C.; GUALTIERI, P.; DORIA, G. P. Dimensional analysis of reaeration rate in streams. Journal of Environmental Engineering. v. 128, n. 1, 2002. https://doi.org/10.1061/(ASCE)0733-9372(2002)128:1(12)

HARANO, F. K.; FERREIRA, M. S., MATEUS, M. V.; FERREIRA, D. C., GONÇALVES, J. C. S. I. Reaeration and oxygen dissipation into a circular hydraulic channel: experimental and dimensionless approach. Revista Brasileira de Recursos Hídricos, v. 23, e12, 2018. https://doi.org/10.1590/2318-0331.231820170138 
HERLINA, V. Gas transfer at the air-water interface in a turbulent flow environment, 2005. 153f. Dissertation (Doctorate) - Institute of Hydromechanics, Karlsruhe University, Karlsruhe, 2005.

HERLINA, V.; JIRKA, G. H. Experiments on gas transfer at the air-water interface induced by oscillating grid turbulence. Journal of Fluid Mechanics, v. 594, p. 183-208, 2008. https://doi.org/10.1017/S0022112007008968

JAMNONGWONG, M.; LOUBIERE, K.; DIETRICH, N.; HÉBRARD, G. Experimental study of oxygen diffusion coefficients in clean water containing salt, glucose or surfactant: Consequences on the liquid-side mass transfer coefficients. Chemical Engineering Journal, v. 165, n. 3, p. 758-768, 2010. https://doi.org/10.1016/j.cej.2010.09.040

JANZEN, G. J.; SCHULZ, H. E.; LAMON, A. W. Medidas da concentração de oxigênio dissolvido na superfície da água. Engenharia Sanitária e Ambiental, v. 13, n. 3. p. 1-6, 2008. http://dx.doi.org/10.1590/S1413-41522008000300006

JANZEN, J. G.; HERLINA, H.; JIRKA, G. H.; SCHULZ, H. E.; GULLIVER, J. S. Estimation of mass transfer velocity based on measured turbulence parameters. AIChE Journal, v. 56, n. 8, p. 2004-2017, 2009. https://doi.org/10.1002/aic.12123

JIMENEZ, M.; DIETRICH, N.; GRACE, J. R.; HÉBRARD, G.; Oxygen mass transfer and hydrodynamic behaviour in wastewater: Determination of local impact of surfactants by visualization techniques. Water Research, v. 58, p. 111-121, 2014. https://doi.org/10.1016/j.watres.2014.03.065

LEWIS, W. K.; WHITMAN, W. G. Principles of gas absorption. Industrial and Engineering Chemistry, v. 16, n. 12, p. 1215-1210, 1924. https://doi.org/10.1021/ie50180a002

MATEUS, M. V.; ARAÚJO, L. S.; LEOPOLDINO A. B.; FERREIRA, M. de S.; FERREIRA, D. C.; da LUZ, M. S.; GONÇALVES J. C. S. I. Molecular interactions and modeling of anionic surfactant effect on oxygen transfer in a cylindrical reactor. Environmental $\begin{array}{llllllll}\text { Engineering } & \text { Science, } & \text { v. } & 36, & \text { n. } & 2, & \text { p. } & 180-185,\end{array}$ https://doi.org/10.1089/ees.2018.0217

MATEUS, M. V.; GONÇALVES J. C. S. I.; JÚNIOR, G. B. L.; OKURA, M. H. Análise de incerteza e modelagem de qualidade da água do Rio Uberaba, Minas Gerais. Revista Brasileira de Ciências Ambientais, n. 37, p. 1-15, 2015. https://doi.org/10.5327/Z2176947820159914

MCKENNA, S. P.; MCGILLIS, W. R. The role of free-surface turbulence and surfactants in air-water gas transfer. International Journal of Heat and Mass Transfer, v. 47, n. 3, p. 539-553, 2004. https://doi.org/10.1016/j.ijheatmasstransfer.2003.06.001

MENEZES, J. P. C.; BITTENCOURT, R. P.; FARIAS, M. de S.; BELLO, I. P.; de OLIVEIRA, L. F. C.; FIA, R. Deoxygenation rate, reaeration and potential for self-purification of a small tropical urban stream. Revista Ambiente \& Água, v. 10, n. 4, p.748-757, 2015. http://dx.doi.org/10.4136/ambi-agua.1599

MENNI, Y.; AZZI, A. Numerical Analysis of Thermal and Aerodynamic Fields in a Channel with Cascaded Baffles. Periodica Polytechnica Mechanical Engineering, v. 62, n. 1, p. 16-25, 2018. https://doi.org/10.3311/PPme.10613 
MOOG, D. B.; JIRKA, G. H. Air-water gas transfer in uniform channel flow. Journal of Hydraulic Engineering, v. 125, n. 1, 1999. https://doi.org/10.1061/(ASCE)07339429(1999)125:1(3)

MORAVEJI, M. K.; PASAND, M. M.; DAVARNEJAD, R.; CHISTI, Y. Effects of surfactants on hydrodynamics and mass transfer in a split-cylinder airlift reactor. The Canadian Journal of Chemical Engineering, v. 90, n. 1, p. 93-99, 2011. https://doi.org/10.1002/cjce.20516

ROSSO, D.; HUO, D. L.; STENSTROM, M. K.; Effects of interfacial surfactant contamination on bubble gas transfer. Chemical Engineering Science, v. 61, n. 16, p. 5500-5514, 2006. https://doi.org/10.1016/j.ces.2006.04.018

SANTOS, F. K. G.; ALVES, J. V. A.; DANTAS, T. N. C.; NETO, A. A. D.; JUNIOR, T. V. D.; NETO, E. L. B. Determinação da concentração micelar crítica de tensoativos obtidos a partir de óleos vegetais para uso na recuperação avançada de petróleo. In: PDPETRO, 4., 21-24 Oct. 2007, Campinas. Anais[...] Campinas: ABPG, 2007. p. 1-9.

SILVA, P. de S. L.; MATEUS, M. V.; FERREIRA, D. C.; da LUZ, M. S.; NAVES, E. A. A.; MARTINS, M. M.; CUNHA, L. C. S.; GONÇALVES, J. C. S. I. Humic substances reduce the oxygen mass transfer in the air-water interface. AIChE Journal, v. 66, n. 6, 2020. https://dx.doi.org/10.1002/aic.16971

ZHANG, S.; WANG, D.; BU, F.; ZHANG, X.; FAN, P. Gas-liquid mass transfer in the presence of ionic surfactant: Effect of counter-ions and interfacial turbulence. Surface and Interface Analysis, v. 45, n. 7, p. 1152-1157, 2013. https://doi.org/10.1002/sia.5242 